Ye. M. Lutyi ${ }^{1}$, Dr. Sc. (Tech.), Prof., orcid.org/0000-0001-8349-5560, I. V. Kuzio ${ }^{2}$, Dr. Sc. (Tech.), Prof., orcid.org/0000-0001-9271-6505, V. V. Baryliak ${ }^{1}$, Cand. Sc. (Tech.), orcid.org/0000-0002-1822-8682, O. M. Udovytskyi ${ }^{1}$, Cand. Sc. (Tech.), Assoc. Prof., orcid.org/0000-0003-2234-806X

\title{
DYNAMICS OF THE TWO-DRUM ELECTROMECHANICAL DRIVE OF SUSPENDED TIMBERTRANSPORTING CABLE SYSTEM
}

Purpose. Determination of dynamic load factors in the links of a two-drum drive of a suspended cable timbertransporting plant equipped with an electric motor and an elastic coupling, taking into account the transient electromechanical processes in the drive motor, variable moments of inertia of drive drums, technological load, as well as changes in the coefficients of longitudinal rigidity of moving cables.

Methodology. The developed dynamical model of the drive contains a number of theoretical dependencies, calculation schemes and systems of differential equations that describe the dynamic processes in the two-drum electromechanical drive of the suspended cable timbertransporting plant. The differential equations of the electromagnetic state of the machine, which describe the transient processes in the drive motor, are based on the Park-Goriev equations. Differential equations of mechanical part of the drive motion are developed on the basis of the D'Alembert's method. For the numerical integration of differential equations systems, the modified Euler's method is used.

Findings. The simulation model calculates the dynamic forces that are active in mechanical gears and the drive coupling; potentially dangerous operating modes of the drive of suspended cable are determined. The dependence of the load dynamic factor on the structural parameters of the drive is established. The influence of the length of the free part of the movable cable on the magnitude of the dynamic loads in the drive is investigated.

Originality. For the first time, a dynamic model of the drive of suspended cable timbertransporting plant was proposed which takes into account: transitional electromechanical processes in the drive motor; variable inertia moments of drive drums; variable load acting on drive drums at each of the stages of the technological cycle of the cable plant work. Calculations of the moment of inertia of the drive drum and the moment of the force of the technological resistance that are variable in time are made taking into account the multilayer winding of the cable on the drive drum, as well as the forces of elastic deformation of moving cables.

Practical value. New methods, algorithms and programs have been developed and the existing ones have been improved for calculation of dynamic loads in the coupling and gears of the electromechanical drive of a cable plant with haul-lifting and reversing cables. On the basis of the obtained dependences of load dynamic factor, recommendations for the choice of structural and operational parameters of drives of these plants were developed.

Keywords: suspended cable timbertransporting plant, dynamic drive model, dynamic load

Introduction. Modern trends in the progress of the forestry industry point to the unconditional promising of the use of suspended cable timbertransporting plants as efficient and ecofriendly means of primary transportation of timber in mountainous terrain [1]. The basic scheme of a suspended cable timbertransporting plant with two-drum drive is shown in Fig. 1.

In Fig. 1 the following designations are adopted: $L-$ the length of the cable plant span; $x_{K}\left(t_{0}\right)$ - the coordinate of the cargo carriage at the initial time point $t_{0} ; l_{A}-$ length of the spare cable, which depends on the type of a plant [2].

The technological working cycle of suspended cable timbertransporting plants contains the following stages [3]:

- the removing of the cable slack (characterized by a gradual increase in the cable tension force to a value equal to the weight of the cargo);

- lifting of cargo;

- locking (docking) of cargo with a cargo carriage;

- moving a cargo carriage with a cargo along the carrying cable.

The drive is an important component of the cable plant, which affects its functionality and reliability in general.

Unsolved aspets of the problem. The duration of each stage in the technological cycle is different and depends on the following operating parameters: cargo weight, length of the cable plant span, position coordinate of the cargo carriage at the initial time point, lifting height of cargo and the inclination angle of the chord to the horizon. Special features of the work of the

(C) Lutyi Ye. M., Kuzio I. V., Baryliak V. V., Udovytskyi O. M., 2019 drives of the cable timbertransporting plants are made by the fact that different stages of the technological cycle involve a different number of moving masses, as well as variable moments of inertia of drive drums, technical efforts and lengths of free sections of moving cables. The length of the free sections of the moving cables in the timbertransporting plants can reach several hundred meters, and therefore the value and nature of the dynamic loads in the drive significantly affect also the forces from the elastic deformation of these cables. Consequently, the study of the joint effect of structural and operational parameters on the magnitude of dynamic loads in the links of the drives of cable timbertransporting plants, taking into account the stages of the technological cycle of work, is an actual scientific and technical task.

Literature review. Scientific research on dynamics of drives of machines relates to various branches of industry: mining [4], logging [5] and others [6]. In most mathematical models of drives, the correlation between electromagnetic phenomena in an electric motor and mechanical vibrations of the system is taken into account. In some studies, in addition to the characteristics of auxiliary engines, free sections of mobile cables were taken into account in the form of discrete [5] and continually discrete [6] mathematical models. Such mathematical models of drives do not take into account multilayer winding of ropes on drive drums and are suitable only for the investigation of short-term transient modes in the absence of a significant change in inertia-mass characteristics of drive drums and free sections of moving cables, and the number of consolidated moving masses in mass models during the investigated time interval is unchanged. 


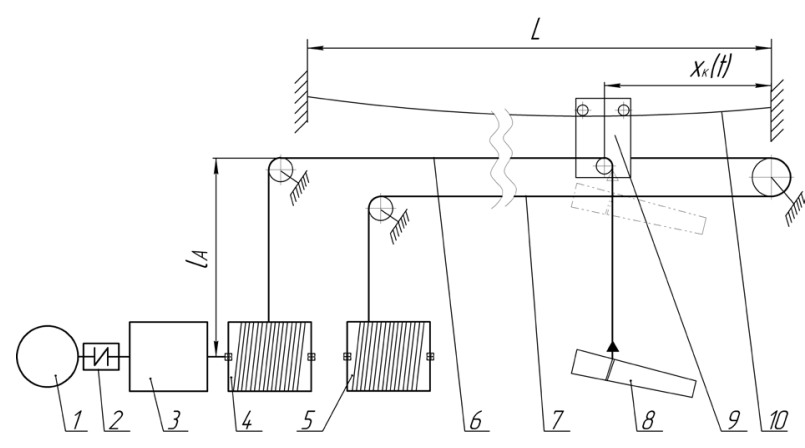

Fig. 1. Principal scheme of a suspended cable timbertransporting plant with two-drum drive:

1 - the engine; 2 - coupling; 3 - mechanical transmission; 4 drive drum of the working motion; 5 - reverse drive drum; $6-$ haul-lifting cable; 7 - reverse cable; 8 - cargo; 9-cargo carriage; 10 - carrying cable

In most of the analyzed studies on the dynamics of drives the most unfavorable operational mode is considered to be the mode of starting [7] or braking [8]. However, the feature of cable timbertransporting plants lies in the fact that maximum external loading can act on the drive not only at the time of starting, but during the next stages of operation. This feature is due to the actual nature of the change in the tensile strength of the haul-lifting cable [3], as well as to the growth of the external rotating moment from the resistance forces due to the multilayer cable winding on the drum. Therefore, the dynamics of drives of cable timbertransporting plants requires additional research taking into account the multilayer cable winding on drive drums, the design features of the drive and the technological conditions of work of the cable plant.

The dynamic drive model contains a calculation scheme with reduced parameters and a mathematical model. Fig. 2 shows the calculation scheme of a two-drum drive of a suspended cable timbertransporting plant equipped with an elastic coupling. A link was made to the engine shaft.

In Fig. 2 such denotations are accepted: $I_{1}-$ moment of inertia of rotating moving masses of the engine and couplings; $I_{2}$ - the combined moment of inertia of the drive gears; $I_{3}(t)-$ the combined moment of inertia of the drive drum with the wound haul-lifting cable on it; $I_{4}(t)$ - the combined moment of inertia of the drive drum with the wound reverse cable; $m(t)$ - the combined onward weight, which is equivalent to the mass of the cargo, the cargo carriage and moving cable;

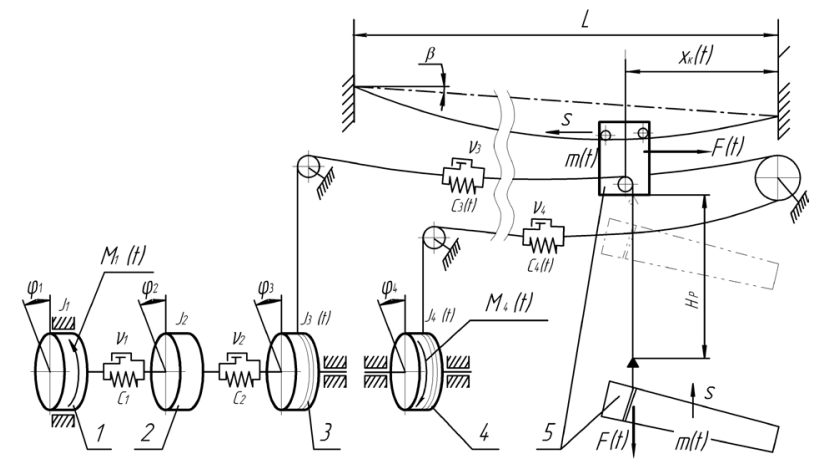

Fig. 2. Calculation scheme of a two-drum timbertransporting plant drive:

1 - rotational mass of the engine and couplings; 2 - rotational mass of the mechanical gears of the drive; 3 - rotational mass of the drive drum with the haul-lifting cable on it; 4 - the combined rotational mass of the drive drum with the wound reverse cable on it; 5 - the combined onward mass, which is equivalent to the mass of the cargo carriage with the load and to the masses of free sections of the moving cables
$M_{1}(t)$ - torque of engine driving forces; $F(t)-$ the combined force of resistance to the displacement of the combined onward mass; $M_{4}(t)$ - the combined moment from the forces of resistance of the movement of the reverse cable and the resistance of the rotation of the drive drum with the reverse cable; $c_{1}, v_{1}-$ respectively, the coefficients of the torsional stiffness and the viscous coupling resistance; $c_{2}, v_{2}$ - respectively, the combined coefficients of the torsional stiffness and viscous resistance of transmission gears; $c_{3}(t), c_{4}(t)-$ combined coefficients of longitudinal stiffness of free sections of moving cables; $v_{3}, v_{4}-$ combined coefficients of viscous resistance of moving cables; $\varphi_{1}, \varphi_{2}, \varphi_{3}, \varphi_{4}, s-$ the combined coordinates of the moving masses of the dynamic model; $L-$ span length; $\beta$ - inclination angle of the span chord; $H_{p}$ - lifting height; $x_{K}(t)$ - the coordinate of the cargo carriage.

In the case of equipping the drive with an asynchronous motor with a short-circuited rotor, the transient electromagnetic processes in the drive engine are described on the basis of the Park-Gorev equations. The electromagnetic moment of the engine $M_{E}$ is calculated by the formula [6]

$$
M_{E}=\frac{2}{3} p_{0} \frac{1}{\tau}\left(i_{R x} i_{S y}-i_{R y} i_{S x}\right),
$$

where $p_{0}$ is the number of pairs of magnetic poles; $i_{S x}, i_{S y}, i_{R x}$, $i_{R y}$ are projections of currents in windings of stator and rotor of the engine on the coordinate axis $x, y$; $\tau$ is a magnitude that is determined from the magnetization curve. The lower index $R$ points out to belonging of the value to the rotor windings, and $S$ is the stator.

The projections of currents $i_{S x}, i_{S y}, i_{R x}, i_{R y}$ are determined from the differential equations of the electromagnetic state of the machine, which are written in the matrix form

$$
\begin{aligned}
& \frac{d i_{S}}{d t}=A_{S}\left(u_{S}+\Omega_{S} \psi_{S}-R_{S} i_{S}\right)+B_{S}\left(\Omega_{R} \psi_{R}-R_{R} i_{R}\right) ; \\
& \frac{d i_{R}}{d t}=A_{R}\left(\Omega_{R} \psi_{R}-R_{R} i_{R}\right)+B_{R}\left(u_{S}+\Omega_{S} \psi_{S}-R_{S} i_{S}\right),
\end{aligned}
$$

where $i_{S}, i_{R}, u_{S}$ are matrix-columns of currents and voltages; $A_{S}, B_{S}, A_{R}, B_{R}$ are square matrices of connection; $\Omega_{S}, \Omega_{R}$ are matrices of rotational frequencies; $\psi_{S}, \psi_{R}$ are matrix-columns of full flow connections; $R_{S}, R_{R}$ are active resistances.

At each stage of the technological cycle, a different number of moving masses will be involved, and therefore the mathematical model will contain a different number of heterogeneous differential equations that describe the motion of the mechanical part of the drive. Therefore, it is necessary to establish boundary conditions that determine the time interval limits of the duration of each of the technological stages.

In order to determine the time of cable slack removing, we assume that the conditional, combined longitudinal deformation of the cable system during this time equals the length of the haul-lifting cable that is wound on the drive drum at the same time $t_{1}$. By the moment of the beginning of cargo lifting up from the ground, the cargo is stationary, and at the moment of cargo lifting up from the ground, the tensile force in the the haul-lifting cable is equal to the weight of the cargo. Expressing the conditional combined deformation of the cable system $c_{K ? B}$ as the weight of the cargo $Q$ and equating it with the length of the haul-lifting cable wound in time $t_{1}$, we obtain

$$
v \cdot t_{1}=\frac{Q}{c_{k Z V}}=\frac{Q\left[L-x_{K}\left(t_{0}\right)\right]}{C_{Z V}},
$$

where $C_{Z V}$ is the longitudinal stiffness of the haul-lifting cable; $v$ is the speed of winding the rope.

Taking into account (3), the time limits of the first stage are

$$
0 \leq t_{1} \leq \frac{Q\left[L-x_{K}\left(t_{0}\right)\right]}{C_{Z V} \cdot v} .
$$


The time limits of the duration of the load lifting phase $t_{2}$ depend on the rope winding speed on the drive drum and the load lifting height

$$
\frac{Q\left[L-x_{K}\left(t_{0}\right)\right]}{C_{Z V} \cdot v}<t_{2} \leq \frac{1}{v}\left(\frac{Q\left[L-x_{K}\left(t_{0}\right)\right]}{C_{Z V}}+H_{P}\right) .
$$

The time of locking $t_{3}$ depends, basically, on the qualification of the operator of the winch and lasts $0.3-0.8 \mathrm{~s}$, but in some cases it can reach $2 \mathrm{~s}$ [2]. Time limits for the duration of the stage $t_{3}$, when the load is docked with a cargo carriage, are

$$
\left\{\begin{array}{l}
\frac{1}{v}\left(\frac{Q\left[L-x_{K}\left(t_{0}\right)\right]}{C_{Z V}}+H_{P}\right)<t_{3} \\
t_{3} \leq \frac{1}{v}\left(\frac{Q\left[L-x_{K}\left(t_{0}\right)\right]}{C_{Z V}}+H_{P}\right)+t_{C}
\end{array},\right.
$$

where $t_{C}$ is the accepted value of the time of load locking with the cargo carriage.

The duration of the cargo movement stage $t_{4}$ is determined from the condition that the length of the haul-lifting cable wound during this time on the drum should not exceed the length of the free section of the haul-lifting cable between the drive and the coordinate of the carriage at the initial moment of time $x_{K}\left(t_{0}\right)$. When calculating the length of the cable free section between the carriage and the drive we accept the sagging trajectory of the cable along a parabola. Conditions for determining the duration of the carriage displacement $t_{4}$ are

$$
\left\{\begin{array}{l}
t_{4}>\frac{1}{v}\left(\frac{Q\left[L-x_{K}\left(t_{0}\right)\right]}{C_{Z V}}+H_{P}\right)+t_{C} \\
t_{4} \leq \frac{1}{v}\left(\frac{Q\left[L-x_{K}\left(t_{0}\right)\right]}{C_{Z V}}+H_{P}+\frac{\left(L-x_{K}\left(t_{0}\right)\right)}{\cos \beta}+\right. \\
\left.+\frac{\left(g q_{K}\right)^{2} \cdot\left(L-x_{K}\left(t_{0}\right)\right)^{3}}{24 \cdot H^{2}} \cos \beta\right)+t_{C}
\end{array}\right.
$$

where $\beta$ is the angle of inclination of the span chord; $H$ is horizontal component of the tension of the cable; $q_{K}$ is the strain mass of the cable; $g$ is free fall acceleration.

To take into account the deformation of the movable cables in the differential equations of motion of the mechanical part of the drive, it is necessary to write expressions to determine the magnitude and speed of the change in the longitudinal deformation of these cables for each stage.

In the time interval $t \in\left[0 ; t_{1}\right]$ that corresponds to the initial stage of the cable slack removing, the cargo, the cargo carriage and the reverse drum with reverse cable will remain fixed. The resistance force moment, which arises due to elastic deformation of the haul-lifting cable, will act on the drive drum. Since, at this stage, the load is still, the conditional combined longitudinal deformation of the haul-lifting cable $\Delta l_{T}(t)$ can be equated to the length of the cable wound on the drum during this initial period. The length of the cable wound on the drum can be expressed through the rotation angle of the drive drum, on which the rope winds

$$
\Delta l_{T}(t)=\varphi_{3} \cdot r_{H}(t),
$$

where $r_{H}(t)$ is the variable winding radius of the haul-lifting cable.

The variable radius of a drum with a wound cable at any given moment of time is calculated by the formula

$$
r_{H}(t)=\frac{d_{B 3}}{2}+d_{K} \cdot\left(n^{\prime}(t)-0,5\right),
$$

where $d_{B 3}$ is the diameter of the drum without a cable; $d_{K}$ is the diameter of the cable; $n^{\prime}(t)$ is the number of layers of the wound cable [4].

Taking into account the variable winding radius, the expression for determining the velocity of elastic deformation of the haul-lifting cable is obtained as a result of differentiation (8)

$$
\frac{d}{d t}\left[\varphi_{3} \cdot r_{H}(t)\right]=r_{H}(t) \frac{d \varphi_{3}}{d t}+\varphi_{3} \frac{d\left[r_{H}(t)\right]}{d t} .
$$

Differential equations that describe the motion of a mechanical part of the drive and take into account (6) and (7), are written on the basis of the D'Alembert's principle in the normal form of Cauchy

$$
\left\{\begin{array}{l}
I_{1} \frac{d^{2} \varphi_{1}}{d t^{2}}=M_{1}(t)-v_{1}\left(\frac{d \varphi_{1}}{d t}-\frac{d \varphi_{2}}{d t}\right)-c_{1}\left(\varphi_{1}-\varphi_{2}\right) \\
I_{2} \frac{d^{2} \varphi_{2}}{d t^{2}}=v_{1}\left(\frac{d \varphi_{1}}{d t}-\frac{d \varphi_{2}}{d t}\right)+c_{1}\left(\varphi_{1}-\varphi_{2}\right)- \\
-v_{2}\left(\frac{d \varphi_{2}}{d t}-\frac{d \varphi_{3}}{d t}\right)-c_{2}\left(\varphi_{2}-\varphi_{3}\right) \\
I_{3}(t) \frac{d^{2} \varphi_{3}}{d t^{2}}=v_{2}\left(\frac{d \varphi_{2}}{d t}-\frac{d \varphi_{3}}{d t}\right)+c_{2}\left(\varphi_{2}-\varphi_{3}\right)-c_{3}(t) \cdot \varphi_{3} \cdot r_{H}^{2}(t)- \\
-v_{3}\left[r_{H}(t) \frac{d \varphi_{3}}{d t}+\varphi_{3} \frac{d\left[r_{H}(t)\right]}{d t}\right] r_{H}(t)-\frac{1}{2} \frac{d \varphi_{3}}{d t} \frac{d\left[I_{3}(t)\right]}{d t}
\end{array}\right.
$$

The first two differential equations of the system (11) describing the motion of the combined masses equivalent to the engine, coupling and transmission of the drive will remain unchanged at all stages of the drive operation.

In the time interval $t \in\left[t_{1} ; t_{2}\right]$ there will be a separation from the support surface and further lifting of the load. The drive drum with a reverse cable and a cargo carriage will remain fixed.

Conditional longitudinal deformation of the haul-lifting cable, taking into account the displacement of the combined onward mass, can be determined by the formula

$$
\Delta l_{T}(t)=\varphi_{3} \cdot r_{H}(t)-s .
$$

As a result of the differentiation (12) we obtain an expression for determining the velocity of elastic deformation of the haul-lifting cable at this stage

$$
\frac{d}{d t}\left[\varphi_{3} \cdot r_{H}(t)-s\right]=r_{H}(t) \frac{d \varphi_{3}}{d t}+\varphi_{3} \frac{d\left[r_{H}(t)\right]}{d t}-\frac{d s}{d t} .
$$

Differential equations describing the movement of the mechanical part of the drive when lifting the load, will be written in the normal form of Cauchy, taking into account the expressions $(12,13)$

$$
\left\{\begin{array}{l}
I_{1} \frac{d^{2} \varphi_{1}}{d t^{2}}=M_{1}(t)-v_{1}\left(\frac{d \varphi_{1}}{d t}-\frac{d \varphi_{2}}{d t}\right)-c_{1}\left(\varphi_{1}-\varphi_{2}\right) \\
I_{2} \frac{d^{2} \varphi_{2}}{d t^{2}}=v_{1}\left(\frac{d \varphi_{1}}{d t}-\frac{d \varphi_{2}}{d t}\right)+c_{1}\left(\varphi_{1}-\varphi_{2}\right)-v_{2}\left(\frac{d \varphi_{2}}{d t}-\frac{d \varphi_{3}}{d t}\right)-c_{2}\left(\varphi_{2}-\varphi_{3}\right) \\
I_{3}(t) \frac{d^{2} \varphi_{3}}{d t^{2}}=v_{2}\left(\frac{d \varphi_{2}}{d t}-\frac{d \varphi_{3}}{d t}\right)+c_{2}\left(\varphi_{2}-\varphi_{3}\right)-c_{3}(t) \cdot\left(\varphi_{3} \cdot r_{H}(t)-s\right) r_{H}(t)-v_{3}\left[r_{H}(t) \frac{d \varphi_{3}}{d t}+\varphi_{3} \frac{d\left[r_{H}(t)\right]}{d t}-\frac{d s}{d t}\right] r_{H}(t)-\frac{1}{2} \frac{d \varphi_{3}}{d t} \frac{d\left[I_{3}(t)\right]}{d t} . \\
m(t) \frac{d^{2} s}{d t^{2}}=c_{3}(t) \cdot\left(\varphi_{3} \cdot r_{H}(t)-s\right)+v_{3}\left[r_{H}(t) \frac{d \varphi_{3}}{d t}+\varphi_{3} \frac{d\left[r_{H}(t)\right]}{d t}-\frac{d s}{d t}\right]-F(t)-\frac{1}{2} \frac{d s}{d t} \frac{d[m(t)]}{d t}
\end{array}\right.
$$


In the time interval of locking a load with a cargo carriage $t \in\left[t_{2} ; t_{3}\right]$, the displacement of the combined onward mass will not occur, and the generalized coordinate of the combined onward mass is constant and is equal to the combined value of the cargo lifting height

$$
s=H_{P} \cdot u=\text { const, }
$$

where $u$ is the general gear ratio of drive's mechanical transmission.

Since the combined onward mass is still, the conditional combined longitudinal deformation of the haul-lifting cable can be equated to the length of the cable wound on the drum during locking, and expressed through the rotation angle of the drive drum

$$
\Delta l_{T}(t)=\varphi_{3} \cdot r_{H}(t)-H_{P} \cdot u .
$$

The velocity of the combined elastic deformation of the haul-lifting cable at this stage can be determined by the (8). Let us write the differential equations of motion of a mechanical part of the drive during locking in the normal form of the Cauchy, taking into account the expressions $(10,15)$

$$
\left\{\begin{array}{l}
I_{1} \frac{d^{2} \varphi_{1}}{d t^{2}}=M_{1}(t)-v_{1}\left(\frac{d \varphi_{1}}{d t}-\frac{d \varphi_{2}}{d t}\right)-c_{1}\left(\varphi_{1}-\varphi_{2}\right) \\
I_{2} \frac{d^{2} \varphi_{2}}{d t^{2}}=v_{1}\left(\frac{d \varphi_{1}}{d t}-\frac{d \varphi_{2}}{d t}\right)+c_{1}\left(\varphi_{1}-\varphi_{2}\right)-v_{2}\left(\frac{d \varphi_{2}}{d t}-\frac{d \varphi_{3}}{d t}\right)-c_{2}\left(\varphi_{2}-\varphi_{3}\right) \\
I_{3}(t) \frac{d^{2} \varphi_{3}}{d t^{2}}=v_{2}\left(\frac{d \varphi_{2}}{d t}-\frac{d \varphi_{3}}{d t}\right)+c_{2}\left(\varphi_{2}-\varphi_{3}\right)-c_{3}(t) \cdot\left(\varphi_{3} \cdot r_{H}(t)-H_{P}\right) r_{H}(t)-v_{3}\left[r_{H}(t) \frac{d \varphi_{3}}{d t}+\varphi_{3} \frac{d\left[r_{H}(t)\right]}{d t}\right] r_{H}(t)- \\
-F(t) r_{H}(t)-\frac{1}{2} \frac{d \varphi_{3}}{d t} \frac{d\left[I_{3}(t)\right]}{d t}
\end{array} .\right.
$$

If $t \in\left[t_{3} ; t_{4}\right]$ the conditional combined longitudinal deformation of the haul-lifting cable at the transfer stage can be calculated by the (12), and the velosity of elastic deformation of the haul-lifting cable - by the formula (13).

The longitudinal elastic deformation of the free section of the reverse cable is determined as follows

$$
\Delta l_{Z V}(t)=s-H_{P} \cdot u-\varphi_{4} \cdot r_{Z}(t) .
$$

An expression for determining the velocity of elastic deformation of the reverse cable will be obtained as a result of differentiation (17)

$$
\frac{d}{d t}\left[s-H_{P} \cdot u-\varphi_{4} \cdot r_{Z}(t)\right]=\frac{d s}{d t}-r_{Z}(t) \frac{d \varphi_{4}}{d t}-\varphi_{4} \frac{d\left[r_{Z}(t)\right]}{d t} .
$$

Differential equations of motion of the mechanical part of the drive in the time interval $t \in\left[t_{3} ; t_{4}\right]$ will have the form

$$
\left\{\begin{array}{l}
I_{1} \frac{d^{2} \varphi_{1}}{d t^{2}}=M_{1}(t)-v_{1}\left(\frac{d \varphi_{1}}{d t}-\frac{d \varphi_{2}}{d t}\right)-c_{1}\left(\varphi_{1}-\varphi_{2}\right) \\
I_{2} \frac{d^{2} \varphi_{2}}{d t^{2}}=v_{1}\left(\frac{d \varphi_{1}}{d t}-\frac{d \varphi_{2}}{d t}\right)+c_{1}\left(\varphi_{1}-\varphi_{2}\right)-v_{2}\left(\frac{d \varphi_{2}}{d t}-\frac{d \varphi_{3}}{d t}\right)-c_{2}\left(\varphi_{2}-\varphi_{3}\right) \\
I_{3}(t) \frac{d^{2} \varphi_{3}}{d t^{2}}=v_{2}\left(\frac{d \varphi_{2}}{d t}-\frac{d \varphi_{3}}{d t}\right)+c_{2}\left(\varphi_{2}-\varphi_{3}\right)-c_{3}(t) \cdot\left(\varphi_{3} \cdot r_{H}(t)-s\right) r_{H}(t)- \\
-v_{3}\left[r_{H}(t) \frac{d \varphi_{3}}{d t}+\varphi_{3} \frac{d\left[r_{H}(t)\right]}{d t}-\frac{d s}{d t}\right] r_{H}(t)-\frac{1}{2} \frac{d \varphi_{3}}{d t} \frac{d\left[I_{3}(t)\right]}{d t} \\
m(t) \frac{d^{2} x}{d t^{2}}=c_{3}(t) \cdot\left(\varphi_{3} \cdot r_{H}(t)-s\right)+v_{3}\left[r_{H}(t) \frac{d \varphi_{3}}{d t}+\varphi_{3} \frac{d\left[r_{H}(t)\right]}{d t}-\frac{d s}{d t}\right]-F(t)-c_{4}(t) \cdot\left(s-H_{P}-\varphi_{4} \cdot r_{Z}(t)\right)+ \\
+v_{4}\left[\frac{d s}{d t}-r_{Z}(t) \frac{d \varphi_{4}}{d t}-\varphi_{4} \frac{d\left[r_{Z}(t)\right]}{d t}\right]-\frac{1}{2} \frac{d s}{d t} \frac{d[m(t)]}{d t}\left[\begin{array}{l}
d t \\
I_{4}(t) \frac{d^{2} \varphi_{4}}{d t^{2}}=c_{4}(t) \cdot\left(s-H_{P}-\varphi_{4} \cdot r_{Z}(t)\right) \cdot r_{Z}(t)+v_{4}\left[\frac{d s}{d t}-r_{Z}(t) \frac{d \varphi_{4}}{d t}-\varphi_{4} \frac{d\left[r_{Z}(t)\right]}{d t}\right] \cdot r_{Z}(t)-S_{4}(t) \cdot r_{Z}(t)-\frac{1}{2} \frac{d \varphi_{4}}{d t} \frac{d\left[I_{4}(t)\right]}{d t}
\end{array}\right.
\end{array}\right.
$$

where $S_{4}(t)$ is the combined force of the rotation resistance of the drive drum with the reverse rope.

The combined force that takes into account the variable external forces of the resistance of the displacement of the onward mass at each of the stages of operation can be determined from the following dependences [2]

$$
\left\{\begin{array}{l}
\left(t_{1} \leq t<t_{2}\right) \Rightarrow F(t)=\frac{Q}{u} \\
\left(t_{2}<t \leq t_{3}\right) \Rightarrow F(t)=\frac{Q\left(\frac{v}{\sqrt{\frac{Q \cdot\left[L-x_{\hat{E}}\left(t_{0}\right)\right]}{C_{Z V}} \cdot g}}\right)}{u} \\
\left(t_{3}<t \leq t_{4}\right) \Rightarrow F(t)=\frac{S(t)}{u}
\end{array}\right.
$$

where $S(t)$ is the tension force of the haul-lifting cable.
The increase in the magnitude of the variable combined onward mass $m(t)$ is taken into account for each following stage of the technological cycle of the cable plant [2]

$$
\left\{\begin{array}{l}
\left(t_{1} \leq t<t_{2}\right) \Rightarrow m(t)=\frac{1}{g \cdot u^{2}}\left(Q+\frac{q_{T} \cdot l_{0 \Sigma}^{T}(t)}{3}\right) \\
\left(t_{2}<t \leq t_{3}\right) \Rightarrow m(t)=\frac{1}{g \cdot u^{2}}\left(Q+G+\frac{q_{T} \cdot l_{0 \Sigma}^{T}(t)}{3}\right), \\
\left(t_{3}<t \leq t_{4}\right) \Rightarrow m(t)=\frac{1}{g \cdot u^{2}}\left(Q+G+\frac{q_{T} \cdot l_{0 \Sigma}^{\grave{O}}(t)}{3}\right)+ \\
+\frac{q_{4} \cdot l_{0 \Sigma}^{4}(t)}{3 g \cdot u^{2} \cdot u_{K}(t)^{2}}
\end{array},\right.
$$

where $u_{K}(t)$ is the variable transmission ratio of the mechanical cable transmission, formed by two drive drums and a mobile 
cable; $l_{0 \Sigma}^{T}(t), l_{0 \Sigma}^{4}(t)$ is the total length of free sections, respectively, traction and return ropes

$$
\left\{\begin{array}{l}
l_{0 \Sigma}^{\grave{O}}(t)=\frac{L-x_{K}(t)}{\cos \beta}+\frac{q_{T}^{2} \cdot\left[L-x_{K}(t)\right]^{3}}{24 H^{2}} \cos \beta \\
l_{0 \Sigma}^{4}(t)=\frac{L+x_{K}(t)}{\cos \beta}+\frac{q_{4}^{2} \cdot\left[L+x_{K}(t)\right]^{3}}{24 H^{2}} \cos \beta
\end{array} .\right.
$$

In contrast to the elastic sections of the drive shafts, in which oscillations may cause alternating deformations and dynamic loads, in moving cables, in longitudinal vibrations, deformations and dynamic loads of only one sign will occur [8]. This feature is due to the fact that the cables are modeled with flexible threads that work only on tension. Implemention of additional conditions in the mathematical model that take into account elastic deformation in one direction can be achieved by introducing accessorial coefficients $K_{C}$ and $K_{C Z}$ into expressions for determining the combined coefficients of longitudinal rigidity of moving cables. The dependencies for determining the combined coefficient of longitudinal rigidity of the haul-lifting cable are written as follows

$$
\left\{\begin{array}{l}
\left(0 \leq t \leq t_{2}\right) \Rightarrow c_{3}(t)=\frac{K_{C} \cdot C_{Z V}}{u^{2}\left(L-x_{K}\left(t_{0}\right)\right)} \\
\left(t_{2}<t \leq t_{3}\right) \Rightarrow c_{3}(t)=\frac{K_{C} \cdot C_{Z V}^{\prime}}{u^{2}\left(L-x_{K}\left(t_{0}\right)\right)}, \\
\left(t_{3}<t \leq t_{4}\right) \Rightarrow c_{3}(t)=\frac{K_{C} \cdot c_{T}(t)}{u^{2}}
\end{array}\right.
$$

where $C_{Z V}, C_{Z V}^{\prime}$ are the combined conditional longitudinal rigidities of the cable system, respectively, when lifting and locking cargo; $c_{T}(t)$ is the coefficient of longitudinal rigidity of the free section of the haul-lifting cable; $K_{C}$ is the coefficient for taking into account a one-way direction of a longitudinal elastic deformation of a haul-lifting cable.

The combined coefficient of longitudinal rigidity of the reverse cable is also determined taking into account the one-way direction of elastic deformation and the variable transmission ratio of the cable transmission

$$
c_{4}(t)=\frac{K_{C Z} \cdot c_{4}(t)}{u^{2} \cdot u_{K}(t)^{2}},
$$

where $K_{C Z}$ is the coefficient for taking into account a one-way direction of a longitudinal elastic deformation of a reverse cable; $c_{4}(t)$ is the coefficient of longitudinal rigidity of the free section of the reverse cable.

Expressing the combined longitudinal deformation of free sections of moving cables through the generalized coordinates of the moving masses of the dynamic model of the drive, we obtain expressions for determining the coefficients $K_{C}$ and $K_{C Z}$

$$
\begin{gathered}
\left\{\begin{array}{c}
\left(\varphi_{3} \cdot r_{H}(t)-s \geq 0\right) \Rightarrow K_{C}=1 \\
\left(\varphi_{3} \cdot r_{H}(t)-s<0\right) \Rightarrow K_{C}=0
\end{array}\right. \\
\left\{\begin{array}{l}
\left(s-H_{P} \cdot u-\varphi_{4} \cdot r_{Z}(t) \geq 0\right) \Rightarrow K_{C Z}=1 \\
\left(s-H_{P} \cdot u-\varphi_{4} \cdot r_{Z}(t)<0\right) \Rightarrow K_{C Z}=0
\end{array}\right.
\end{gathered}
$$

The combined mass $m(t)$ in the dynamic model is equivalent to the mass of the cargo carriage and cargo. Therefore, in order to determine the coefficients of rigidity of free sections of moving cables $c_{T}(t)$ and $c_{4}(t)$ the horizontal coordinate of the cargo carriage $x_{K}(t)$ in the span can be expressed through the generalized coordinate of the combined onward mass

$$
\left\{\begin{array}{l}
\left(0 \leq t \leq t_{3}\right) \Rightarrow x_{K}(t)=x_{K}\left(t_{0}\right) \\
\left(t_{3}<t \leq t_{4}\right) \Rightarrow x_{K}(t)=x_{K}\left(t_{0}\right)+\left(\frac{s}{u}-H_{P}\right) \cos \beta
\end{array} .\right.
$$

A two-drum drive of a cable timbertransporting plant, equipped with an electric motor and an elastic coupling, was accepted for the analysis. Therefore, systems of differential equations $(11,14,16,19)$ describing the motion of a mechanical part of the drive should be solved together with the system (2), which describes the transient electromagnetic processes in the engine. The variable parameters of the dynamic model of a two-drum drive are calculated at each step of the numerical integration of systems of differential equations.

The method of numerical integration of systems of differential equations enables to determine the motion parameters of the mechanical part of the drive: the angles of rotation and angular velocities of the combined rotating masses. According to known motion parameters of the combined masses of the drive, time dependences of the dynamic moments can be constructed. The combined dynamical moments that arise in the mechanical transmissions of the drive, are calculated as follows [9]

$$
M_{f i 2}=c_{2}\left(\varphi_{3}-\varphi_{4}\right)+v_{2}\left[\omega_{3}-\omega_{4}\right] .
$$

The developed dynamic model allows determining the dynamic loads that arise on the shaft of the electric motor, in the coupling, in the mechanical transmissions of the drive, as well as in the moving cables of the timbertransporting plant. In a two-drum electromechanical drive at the beginning of the movement, all masses are fixed, and the currents in the windings of the stator and the rotor are zero. Therefore, the initial conditions for the numerical integration of the systems of differential equations $(2,11,14,16,19)$ will be as follows

$$
\begin{gathered}
t_{0}=0 ; \quad i_{S x}\left(t_{0}\right)=0 ; \quad i_{S y}\left(t_{0}\right)=0 ; \quad i_{R x}\left(t_{0}\right)=0 ; \\
i_{R y}\left(t_{0}\right)=0 ; \quad \varphi_{1}\left(t_{0}\right)=0 ; \quad \varphi_{2}\left(t_{0}\right)=0 ; \quad \varphi_{3}\left(t_{0}\right)=0 ; \\
x\left(t_{0}\right)=0 ; \quad \varphi_{4}\left(t_{0}\right)=0 ; \quad \omega_{1}\left(t_{0}\right)=0 ; \quad \omega_{2}\left(t_{0}\right)=0 ; \\
\omega_{3}\left(t_{0}\right)=0 ; \quad v\left(t_{0}\right)=0 ; \quad \omega_{4}\left(t_{0}\right)=0 .
\end{gathered}
$$

Results. Numerical integration of differential equations and further calculation of dynamic moments are performed in Mathcad 15.0. An example of calculation of angular velocities and dynamic moments in an electromechanical drive of a suspended cable timbertransporting plant with an elastic coupling is shown in Figs. $3-5$ in the form of diagrams. Incoming data for calculation are: engine 4A180M4 $\left(R_{S}=0.134 \mathrm{Om} ; R_{R}=\right.$ $=0.117 \mathrm{Om} ; L_{S}=0.8 \cdot 10^{-3} \mathrm{H} ; L_{R}=0.82 \cdot 10^{-3} \mathrm{H} ; L_{m}=$ $=4.9 \cdot 10^{-2} \mathrm{H} ; U_{m}=310.5 \mathrm{~W} ; a_{1}=4.714 \cdot 10^{-2} \mathrm{~Wb} / \mathrm{A} ; a_{2}=$ $=-2.094 \cdot 10^{-5} \mathrm{~Wb} / \mathrm{A}^{3} ; a_{3}=6.003 \cdot 10^{-9} \mathrm{~Wb} / \mathrm{A}^{5} ; i_{m k}=15.0 \mathrm{~A}$; $\left.\omega_{0}=157 \mathrm{rad} / \mathrm{s} ; p_{0}=2\right) ; J_{1}=23.5 \mathrm{~kg} \cdot \mathrm{m}^{2} ; \mathrm{J} 2=0.02 \mathrm{~kg} \cdot \mathrm{m}^{2}$; $c_{1}=30 \cdot 10^{3} \frac{\mathrm{N} \cdot \mathrm{m}}{\mathrm{rad}} ; \quad c_{1}=40 \cdot 10^{3} \frac{\mathrm{N} \cdot \mathrm{m}}{\mathrm{rad}} ; \quad v_{1}=15 \frac{\mathrm{N} \cdot \mathrm{m} \cdot \mathrm{s}}{\mathrm{rad}} ; \quad v_{2}=$ $=2.96 \cdot 10^{-3} \frac{\mathrm{N} \cdot \mathrm{m} \cdot \mathrm{s}}{\mathrm{rad}} ; L=400 \mathrm{~m} ; x_{K}\left(t_{0}\right)=80 \mathrm{~m} ; Q=16 \mathrm{kN} ; G=$ $=240 \mathrm{~N} ; u=20 ; H_{G}=4 \mathrm{~m} ; m_{B 3}=30 \mathrm{~kg} ; L_{B 3}=0.6 \mathrm{~m} ; d_{B 3}=$ $=0.3 \mathrm{~m} ; \mathrm{dK}=9.7 \cdot 10^{-3} \mathrm{~m} ; \beta=30^{\circ}$.

The analysis of the diagrams showed that the acceleration of the drive system lasts less than $0.2 \mathrm{~s}$ (Fig. 3). The initial stage of acceleration is accompanied by intense fluctuations of the electromagnetic moment of the engine (up to $800 \mathrm{~N} \cdot \mathrm{m}$ ) with the frequency of the feeder network of $50 \mathrm{~Hz}$ (Fig. 5). Such a small acceleration time is due to the lack of technological load at the time of start and the gradual linear increase in the tensile strength of the haul-lifting cable at the initial stage of the technological cycle from zero to magnitude $Q$. The amplitudes and the intensity of the oscillations of the combined dynamic moment in the transmissions (Fig. 4) during the startup period are much smaller (up to $15 \mathrm{~N} \cdot \mathrm{m}$ ). The low values of the am- 


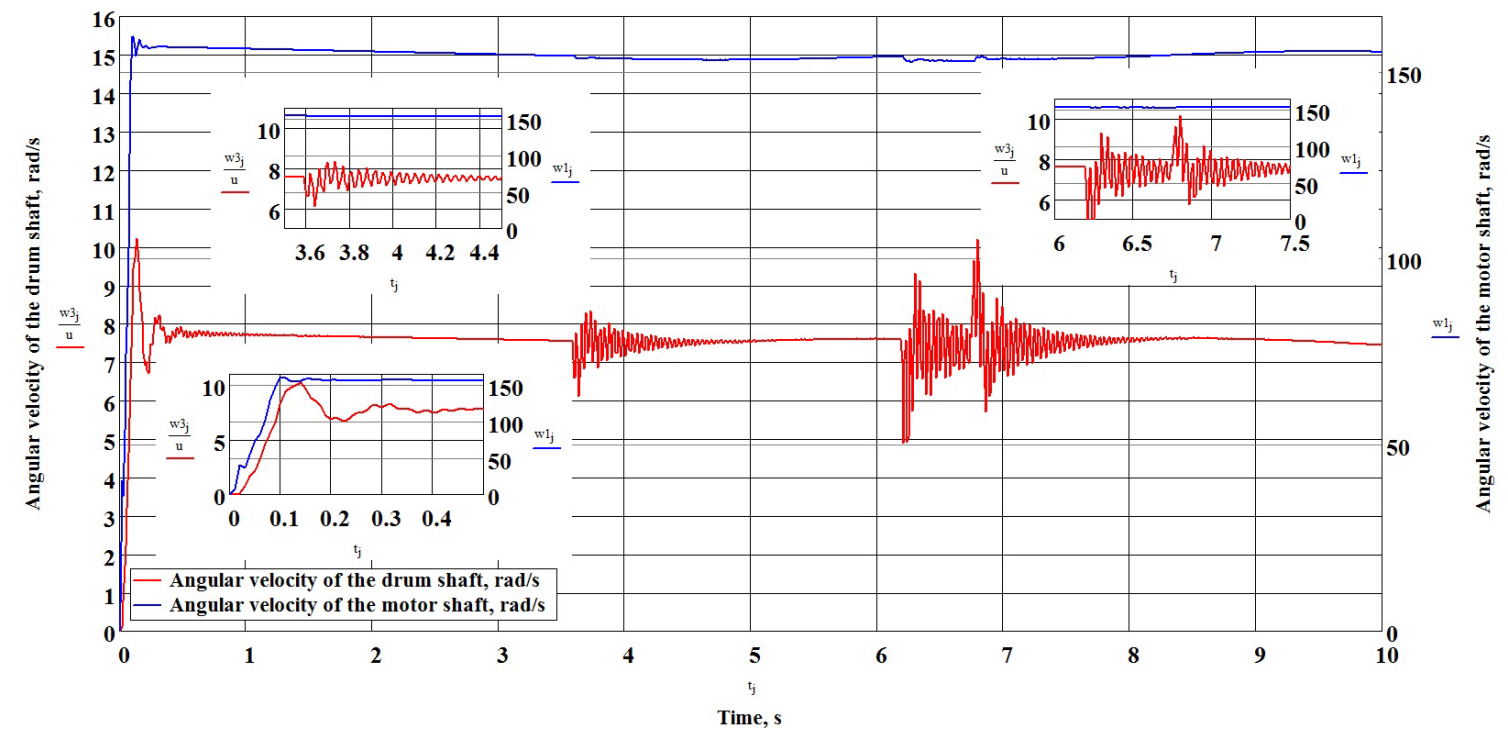

Fig. 3. Time dependences of angular velocities of drive shafts

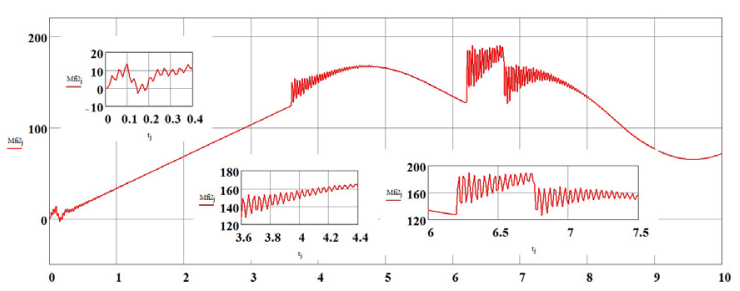

Fig. 4. Time dependence of the combined dynamic moment in mechanical transmissions of the drive

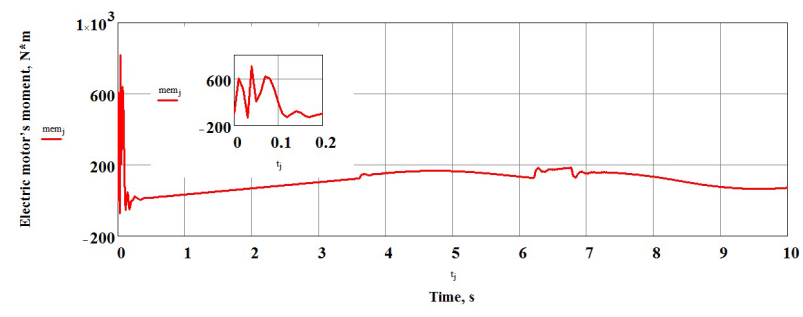

Fig. 5. Time dependences of the combined moment of the electric motor

plitudes and of the intensity of the fluctuations of the dynamic moments in the transmission of the drive during acceleration are also explained by the linear nature of the growth of the technological load and by the decrease in the influence of the oscillation moment of the engine on the transmissions due to the elastic properties of the coupling.

During the cargo lifting up from the supporting surface (at $3-4^{\text {th }}$ second of work) and locking of the cargo with the cargo carriage (at the 6th second of work), synchronous oscillation of the angular velocities of the drive shafts of the electric motor and the drive drum is observed (Fig. 3). In this case, the amplitude of the angular velocity oscillations of the motor shaft (Fig. 3) is greater than during the startup period. The dynamic moment in the transmission line of the drive (Fig. 4) also reaches the maximum values (up to $160 \mathrm{~N} \cdot \mathrm{m}$ ) during the cargo lifting from the supporting surface and during the locking of the cargo with the cargo carriage (up to $185 \mathrm{~N} \cdot \mathrm{m}$ ).

In order to evaluate the influence of the structural parameters of the drive on the dynamic loads of the drive transmission, a simulation was carried out for various values of the weight of the cargo and for the initial coordinate of the cargo carriage in the span. It is defined that in the case of a close position of the cargo carriage to the drive (up to $25-30 \mathrm{~m}$ ) at the locking stage, the dynamic coefficient may acquire the highest values (3-4.7). Such a significant increase in dynamic loads in the drive is due to a rapid increase in the coefficient of longitudinal rigidity of the free section of the hauling cable.

Based on the simulation results, the limits for choosing the values of the combined torsional rigidity coefficient were justified, at which the dynamic load coefficient would be of the smallest values.

Conclusions.

1. For the drive transmissions of cable timbertransporting plants, the startup and acceleration stages are less dangerous than the locking stage of the cargo with the cargo carriage and the lifting of the cargo from the supporting surface.

2. The dynamic load coefficient is the smallest when the combined coefficients of torsional rigidity of transmissions are within $100-125 \mathrm{~N} \cdot \mathrm{m} / \mathrm{rad}$.

3. In the case when the distance between the cargo carriage and the drive is less than $25-30 \mathrm{~m}$, in order to reduce the dynamic loads in the links of the drive it is recommended to carry out the transporting of the timber in a semi-suspended way, avoiding the locking of the cargo carriage with the cargo.

\section{References.}

1. Korzhov, V., \& Cudra, V. (2014). Application of mobile cable timbertransporting plants in the Carpathians. Scientific works of the Forestry Academy of Sciences of Ukraine, (12), 242-250.

2. Lutyy, Ye. M., Barylyak, V. V., \& Udovytskyy, O. M. (2015). Calculation features of variables process loads acting on the cable timbertransporting plants drive. Fo-restry, Forest, Paper and Woodworking Industry. Interdepartmental scientific and technical research collection, (41), 29-39.

3. Ilyin, S. R., Ilyina, S. S., \& Samusya, V. I. (2014). Dynamics of mine rise: monograph. National Mining University. 4. Dzyuba, L., \& Baryliak, V. (2016). Dynamics of electromechanical drive of suspended timbertransporting rope system. Technical Sciences, Olsztyn: University of Warmia and Mazury in Olsztyn, 19(3), 245-256.

5. Semchuk, L. V. (2013). The influence of elastic-inert qualities of the rope on the dynamics of mining elevators. Scientific bulletin of UNFU, 23(2), 371-379.

6. Kharchenko, Ye. V., \& Bondarchuk, B.V. (2012). Mathematical modeling of the electromechanical system start-up processes of a passenger elevator. Bulletin of the National University "Lviv Polytechnic", 730, 99-108.

7. Kharchenko, Ye. V., \& Bondarchuk, B. V. (2012), Mathematical modeling of braking operating modes of the drive system of a passenger elevator. Scientific bulletin of UNFU, 22(13), 294-301. 
8. Kolosov, D. L., Samusya, V. I., Belous, O. I., \& Bobylova, I. T. (2018). Stress-strain state of a flat tractive-bearing element of lifting and transporting machine considering an influence of a complex of factors. Collection of scientific works of NMU, 55, 213-221.

9. Semchuk, L. V., \& Kovalchuk, R. A. (2015). Calculation of Braking Modes of Lifting Facilities of Engineering Structures in View of Mine Type Elastic-inertial Properties Rope. Scientific bulletin of UNFU, 25(4), 173-179.

\section{Динаміка двобарабанного електромеханічного привода підвісної канатної лісотранспортної установки}

\section{Є. М. Лютий' , І. В. Кузьо ${ }^{2}$ В. В. Бариляк 1 , О. М. Удовицький}

1 - Національний лісотехнічний університет України, м. Львів, Україна , e-mail: barylyakw@ nltu.edu.ua 2 - Національний університет „Львівська політехніка“, м. Львів, Україна

Мета. Визначення коефіцієнтів динамічності навантаження в ланках двобарабанного привода підвісної канатної лісотранспортної установки, оснащеного електродвигуном і пружною муфтою, з урахуванням перехідних електромеханічних процесів у приводному двигуні, змінних моментів інерції приводних барабанів, технологічного навантаження, а також зміни коефіцієнтів повздовжньої жорсткості рухомих канатів.

Методика. Розроблена динамічна модель привода містить ряд теоретичних залежностей, розрахункові схеми й системи диференціальних рівнянь, що описують динамічні процеси у двобарабанному електромеханічному приводі підвісної канатної лісотранспортної установки. Диференціальні рівняння електромагнітного стану машини, що описують перехідні процеси у приводному двигуні, базуються на основі рівнянь Парка-Горєва. Диференціальні рівняння руху механічної частини привода розроблені на основі методу Д’Аламбера. Для чисельного інтегрування систем диференціальних рівнянь застосовано модифікований метод Ейлера.

Результати. Методом імітаційного моделювання обчислені динамічні зусилля, що діють у механічних передачах і муфті привода, визначені потенційно небезпечні режими роботи привода підвісної канатної установки. Встановлена залежність коефіцієнта динамічності навантаження від конструкційних параметрів привода. Досліджено вплив довжини вільної ділянки рухомого каната на величину динамічних навантажень у приводі.

Наукова новизна. Уперше запропонована динамічна модель привода підвісної канатної лісотранспортної установки, що враховує: перехідні електромеханічні процеси у приводному двигуні; змінні моменти інерції приводних барабанів; змінне навантаження, що діє на приводні барабани на кожному з етапів технологічного циклу роботи канатної установки. Розрахунки змінних у часі моменту інерції приводного барабана й моменту сили технологічного опору виконані з урахуванням багатошарового намотування каната на приводний барабан, а також сили пружної деформації рухомих канатів.

Практична значимість. Розроблені нові та удосконалені існуючі методики, алгоритми та програми для розрахунків динамічних навантажень у муфті й передачах електромеханічного привода канатної лісотранспортної установки із тягово-вантажопідіймальним і зворотним канатами. На основі отриманих залежностей коефіцієнта динамічності навантаження розроблені рекомендації щодо вибору конструкційних і експлуатаційних параметрів приводів даних установок.
Ключові слова: підвісна канатна лісотранспортна установка, динамічна модель привода, динамічні навантаження

\section{Динамика двухбарабанного электромеханического привода подвесной канатной лесотранспортной установки

\author{
Е.М.Лютый', И. В.Кузьо ${ }^{2}$, В. В. Бариляк ${ }^{1}$,
} А. Н. Удовиикий ${ }^{1}$}

1 - Национальный лесотехнический университет Украины, г. Львов, Украина, e-mail: barylyakw@ nltu.edu.ua 2 - Национальный университет „Львовская политехника“, г. Львов, Украина

Цель. Определение коэффициентов динамичности нагрузки в звеньях двухбарабанного привода подвесной канатной лесотранспортной установки, оснащенного электродвигателем и упругой муфтой, с учетом переходных электромеханических процессов в приводном двигателе, переменных моментов инерции приводных барабанов, технологической нагрузки, а также изменения коэффициентов продольной жесткости подвижных канатов.

Методика. Разработанная динамическая модель привода содержит ряд теоретических зависимостей, расчетные схемы и системы дифференциальных уравнений, описывающих динамические процессы в двухбарабанном электромеханическом приводе подвесной канатной лесотранспортной установки. Дифференциальные уравнения электромагнитного состояния машины, которые описывают переходные процессы в приводном двигателе, базируются на основе уравнений Парка-Горева. Дифференциальные уравнения движения механической части привода разработаны на основе метода Д'Аламбера. Для численного интегрирования систем дифференциальных уравнений применен модифицированный метод Эйлера.

Результаты. Методом имитационного моделирования вычислены динамические усилия, действующие в механических передачах и муфте привода, определены потенциально опасные режимы работы привода подвесной канатной установки. Установлена зависимость коэффициента динамичности нагрузки от конструктивных параметров привода. Исследовано влияние длины свободного участка подвижного каната на величину динамических нагрузок в звеньях приводов.

Научная новизна. Впервые предложена динамическая модель привода подвесной канатной лесотранспортной установки, которая учитывает: переходные электромеханические процессы в приводном двигателе; переменные моменты инерции приводных барабанов; переменную нагрузку, действующую на приводные барабаны на каждом этапе технологического цикла работы канатной установки. Расчеты переменных во времени моментов инерции приводного барабана и момента силы технологического сопротивления выполнены с учетом многослойной навивки каната на приводной барабан, а также силы упругой деформации подвижных канатов.

Практическая значимость. Разработаны новые и усовершенствованы существующие методики, алгоритмы и программы для расчетов динамических нагрузок в муфте и передачах электромеханического привода канатной лесотранспортной установки с тягово-грузоподъемным и обратным канатами. На основании полученных зависимостей коэффициентов динамичности нагрузки разработаны рекомендации для выбора конструкционных и эксплуатационных параметров приводов данных установок.

Ключевые слова: подвесная канатная лесотранспортная установка, динамическая модель привода, динамические нагрузки

Рекомендовано до публікації докт. техн. наук I. T. Ребезнюком. Дата надходження рукопису 06.05.18. 